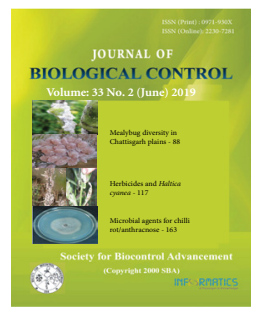

Research Article

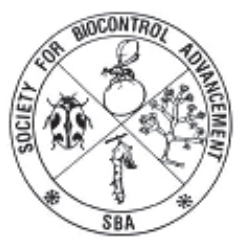

\title{
Biocontrol of five invasive weeds of Meghalaya - A case study
}

\author{
R. K. BORAH*, J. BORAH and S. A. ISLAM \\ ${ }^{1}$ Rain Forest Research Institute, Post Box No. 136, Jorhat - 785001, Assam, India \\ "Corresponding author E-mail: rkborah@gmail.com
}

\begin{abstract}
The state of Meghalaya, in North East India is endowed with a dense cover of natural forest. A vast majority of the forests are owned by communities who traditionally practice shifting cultivation. This has resulted in significant reduction of the original forest area leading to a drastic change in the floristic composition of the state. This is evident by the ubiquitous presence of various invasive weeds such as Mikania micrantha, Chromolaena odorata, Ageratum conyzoides, Spilanthes paniculata and Spermacoce hispida. A survey for natural fungal enemies against these weeds was carried out in the state with the objective of identifying potential biocontrol agents. A total of six pathogenic fungi were isolated from infected leaves of these target weeds. Of these, two fungi isolated from leaf spot and leaf necrosis disease of Mikania micrantha were identified as Gliocladium roseum and Phomopsis sp., respectively. The fungus isolated from S. paniculata, C. odorata, and A. conyzoides was Fusarium solani and from Spermococe hispida it was F. acuminatum. Pathogenicity test carried out on target weeds and agricultural crops grown in Meghalaya (Maize, Chilli, Tomato, Rice and Ginger) showed that all the isolated fungi were found infecting the weeds from which they were isolated and also maize and tomato. They were found non non pathogenic to seedlings of some economically important tree species of Meghalaya, viz., Pinus kesiya, Magnolia champaca, Alnus nepalensis, Chukrasia tabularis, Exbucklandia populnea and Castanopsis indica. Hence, these fungi can be tested in field condition on pilot scale, in forest areas but not in agricultural areas where maize or tomato is grown.
\end{abstract}

KEY WORDS: Biocontrol, Fungi, invasive, meghalaya, weeds

(Article chronicle: Received: 03-09-2018; Revised: 28-02-2019; Accepted: 30-04-2019)

\section{INTRODUCTION}

The state of Meghalaya, comprising of Khasi, Garo and Jaintia hills lying between $25^{\circ} .00^{\prime}$ and $26^{\circ} .10^{\prime} \mathrm{N}$ and $89^{\circ} .45^{\prime}$ and $92^{\circ} .45^{\prime} \mathrm{E}$, is one of the richest state of India in terms of floral diversity and is endowed with a dense cover of natural forest comprising $76.45 \%$ of the total geographical area. A vast majority of the forests in Meghalaya are owned by clan/ communities who traditionally practice shifting cultivation, as part of their socio-religious customs. About $70 \%$ of the state is forested, of which $9,496 \mathrm{~km}^{2}(3,666 \mathrm{sqm}$.) is a dense primary subtropical forest. The forests of Meghalaya are considered to be among the richest botanical habitats of Asia. These forests receive abundant rainfall and support a vast variety of floral faunal biodiversity. The forests of Meghalaya can broadly be grouped under the tropical type and the temperate type, mainly based on the altitude, rainfall and dominant species composition like tropical evergreen forests, tropical semi-evergreen forests, tropical moist forests, dry deciduous forests, grass and savannas, and temperate forests.
The alien plant invasion has been considered as a potential threat to the forest ecosystem in the tropics. It is estimated that as many as $50 \%$ of invasive species in general can be classified as ecologically harmful based on their actual impacts (Richardson et al., 2000). Invasion of the species cause extensive effects on the habitats they invade, like impact on indigenous species diversity, soil nutrient composition, altering forest fire cycles and loss of productivity of invading ecosystems. It also becomes a threat to threatened plant species around the world (Pimentel et al., 2005). Biological invasions posses a major threat to indigenous biological diversity. Invasive alien plants have caused extensive economic and ecological damage throughout the world. Therefore, the effects of biological invasion are increasingly being recognized for the role in degradation of biological diversity worldwide (Usher et al., 1988; D' Antonio and Vitousek, 1992).

A rapid increase in human population, particularly the tribal populations who exclusively practice shifting cultivation (jhum), has resulted in the loss of forest cover and has paved 
the way for the establishment of invasive weed species in areas where several unique native species previously existed. Major weed invasions change the natural diversity and balance of ecological communities. These changes threaten the survival of many plants and animals because the weeds compete with native plants for space, nutrients and sunlight. According to Rao and Sagar (2012), in Meghalaya, several native or naturalized grass species that have otherwise been eaten by cattle have become comparatively rare, for example Bracharia mutica Stapf., B. repens (L.) Gard. Et Hubb., B. distachya Stapf., Paspalidium flabvidum A. Camus, Cytrococcum trigonum A. Camus, Panicum miliare Lamk., etc. Haridasan and Rao (1985) have listed 45 species as being extremely rare, partly due to alterations in the natural habitat caused by invasive weeds.

The entire North Eastern region of India receives heavy rainfall and as a result, weeds and other undesirable plants grow luxuriantly in the cultivated and non-cultivated situations. Keeping the weeds under control has become a major problem in this region. Important invasive plants that have created havoc in a number of habitats in North Eastern India include terrestrial herbaceous weeds (e.g., Ageratum conyzoides), shrubs (e.g., Chromolaena odorata), vines (e.g., Mikania micranthai, and Mimosa diplotricha). These have entered the alien environment by one of two main pathways either intentionally to serve a human purpose or accidently (through import of agriculture/horticulture material, human beings, ballast water etc). To get rid of those weed problems, the chemical herbicides were being used injudiciously which leads to resistance in weed species and also it affects the human and the environment directly or indirectly resulting in an ecological imbalance (Waghmare et al., 2011). Further, herbicidal control cannot be recommended in natural forests because of the unique ecology and possible damage to the non target flora. Exploration of biocontrol agent for controlling the weed species could be an eco-friendly alternative to those hazardous chemicals. Thus, the present investigation was carried out to isolate and identify fungal pathogens naturally occurring on five target weeds, viz., Mikania micrantha, Chromolaena odorata, Ageratum conyzoides, Spilanthes paniculata and Spermococe hispida in Meghalaya state and to assess the potential of these fungal pathogens for weed management.

\section{MATERIALS AND METHODS}

\section{Survey for pathogenic mycobiota}

The survey was carried out during 2016-2017 in different districts of Meghalaya to study the occurrence of disease incidence on the target weeds. The survey covered forest plantations and natural forest areas in all districts of the state.

\section{Symptomatology}

Different symptoms of the prevalent diseases occurring on the target weeds were noted and photographs were taken.

\section{Isolation and identification of the causal organism}

Diseased leaf samples were collected and brought to the laboratory wrapped on a brown paper bag. Fungi were isolated from the transition zone of healthy and diseased tissue of the sample. In isolating the fungi from samples, small pieces of about 2-5 mm of advancing zone of infection were cut and transferred to sterile Petri-dishes. The pieces were surface sterilized for 2-3 minutes in 4.0 per cent sodium hypochlorite $(\mathrm{NaOCl})$. These surface sterilized cut pieces were transferred to the PDA (Potato Dextrose Agar) media in Petri-dishes. A trace amount of streptomycin was added to the media to inhibit the growth of bacterial population. The dishes were incubated at $24 \pm 1{ }^{\circ} \mathrm{C}$ and examined periodically for up to ten days. Identification of pure culture of the fungi from disease specimens were attempted on the basis of their cultural and morphological characters. Bits of mycelia growth obtained from the culture by inserting inoculating needle were mounted in lactophenol-cotton blue stains and sealed with nail polish to make them semi-permanent. The mount so prepared was observed under a compound microscope with a photographic attachment. The morphological features were recorded, measurements made and microphotographs were taken. For authentic identification or confirmation, the fungal cultures were referred to Indian Type Culture Collection (ITCC), Indian Agricultural Research Institute (IARI), New Delhi.

\section{Pathogenicity test}

Tests for pathogenic association of the isolated fungi were made on target weeds, agricultural crops grown in Meghalaya (maize, chilli, tomato, rice and ginger) and also on seedlings of some economically important tree species of Meghalaya, viz., Pinus kesiya, Magnolia champaca, Alnus nepalensis, Chukrasia tabularis, Exbucklandia populnea and Castanopsis indica, and was confirmed through Koch's postulates. Seedlings of these plants were raised in earthen pots filled with sterile soil, under glass house conditions. Two $\mathrm{mm}$ diameter plugs of mycelial agar inoculums taken from ten days old fungal cultures with the help of sterile cork borer were used for inoculation. Control plants were inoculated only with sterilized agar bits. Both inoculated and controlled plants were kept covered with moistened polythene bags for 4 days. Observations were made periodically for symptom development, if any. Soon after the appearance of symptoms, the organism was re-isolated from artificially infected leaves and the isolate obtained was compared with the original culture for confirmation. Re-isolation from artificially infected plants was carried out on PDA. 
Table 1. Study sites for occurrence of disease incidence on the invasive weeds of Meghalaya.

\begin{tabular}{|c|c|c|c|}
\hline Districts & Sites & GPS Co-ordinates & Dominant Species \\
\hline \multirow[t]{7}{*}{ West Garo Hills } & Ballonggre village & $\mathrm{N}-25^{\circ} 31^{\prime} 27.3^{\prime \prime} \mathrm{E}-90^{\circ} 09^{\prime} 9.5^{\prime \prime}$ & Chromolaena odorata \\
\hline & Gambakgre village & $\mathrm{N} 25^{\circ} 32.453^{\prime}$ E $091^{\circ} 09.177^{\prime \prime}$ & C. odorata \\
\hline & Jengjal & $\mathrm{N}-25^{\circ} 39^{\prime} 08.2^{\prime \prime} \mathrm{E}-90^{\circ} 20^{\prime} 7.7^{\prime \prime}$ & Spilanthes paniculata \\
\hline & Chinabat Village & $\mathrm{N} 25^{\circ} 33.086^{\prime} \mathrm{E} 090^{\circ} 22.849^{\prime}$ & Mikania micrantha \\
\hline & Rombagre Village & $\mathrm{N} 25^{\circ} 33.375^{\prime} \mathrm{E} 091^{\circ} 20.224^{\prime}$ & Ageratum conyzoides \\
\hline & Gambakgre Village & $\mathrm{N} 25^{\circ} 32.453^{\prime} \mathrm{E} 091^{\circ} 091.177^{\prime}$ & C. odorata \\
\hline & Balonggre Village & $\mathrm{N} 25^{\circ} 32^{\prime} 441^{\prime \prime} \mathrm{E} 090^{\circ} 09^{\prime} 09.03^{\prime \prime}$ & M. micrantha \\
\hline \multirow[t]{2}{*}{ South Garo Hills } & Bandarigre & $\mathrm{N} 25^{\circ} 23.227^{\prime} \& \mathrm{E} 090^{\circ} 15.399^{\prime}$ & C. odorata \\
\hline & Dekudobagre & $\mathrm{N}-25^{\circ} 21^{\prime} 38.5^{\prime \prime} \mathrm{E}-090^{\circ} 20^{\prime} 33.3^{\prime \prime}$ & C. odorata \\
\hline \multirow[t]{5}{*}{ Ri-bhoi District } & Umiam (U. C. C. Hills) & $\mathrm{N} 25^{\circ} 39.450^{\prime} \mathrm{E} 091^{\circ} 51.49 .6^{\prime}$ & $\begin{array}{l}\text { C. odorata, M. micrantha, } \\
\text { Spilanthes paniculata and } \\
\text { A. conyzoides. }\end{array}$ \\
\hline & (Umroi Village) Lumdiengngam & $\mathrm{N} 25^{\circ} 38.249^{\prime} \mathrm{E} 092^{\circ} 03.566^{\prime \prime}$ & M. micrantha \\
\hline & Mawkhanu village & $\mathrm{N} 25^{\circ} 38.249^{\prime} \mathrm{E} 092^{\circ} 03.566^{\prime \prime}$ & M. micrantha \\
\hline & $\begin{array}{l}\text { Umtasor Range, } \\
\text { Nongkhyllem Reserve Forest }\end{array}$ & N 2550'.004"E 09149’38.5" & $\begin{array}{l}\text { M.micrantha, S. paniculata, A. co- } \\
\text { nyzoides and Spermacoce hispida }\end{array}$ \\
\hline & Byrnihat, $15^{\text {th }}$ Mile & $\mathrm{N} 26^{\circ} 02^{\prime} 20.8^{\prime \prime} \mathrm{E} 091^{\circ} 52^{\prime} .02 .2^{\prime}$ & M. micrantha \\
\hline \multirow[t]{4}{*}{ West Jayantia Hills } & $8^{\text {th }}$ Mile Village & $\mathrm{N} 25^{\circ} 28.191^{\prime}$ E $092^{\circ} 17^{\prime} 24.8^{\prime \prime}$ & M. micrantha \\
\hline & Sabhanous Village & $\mathrm{N} 25^{\circ} 28^{\prime} 28.1^{\prime \prime} \mathrm{E} 092^{\circ} 14^{\prime} 51.2^{\prime \prime}$ & A. conyzoides, S. paniculata \\
\hline & Khliekhtyrshi Village & $\mathrm{N} 25^{\circ} 28^{\prime} 38.7^{\prime \prime} \mathrm{E} 092^{\circ} 10^{\prime} 39.0^{\prime \prime}$ & $\begin{array}{l}\text { Large scale of } A \text {. conyzoides notice } \\
\text { but no disease was found. }\end{array}$ \\
\hline & Mookyndur Village & $\mathrm{N} 25^{\circ} 31^{\prime} 57.5^{\prime \prime} \mathrm{E} 092^{\circ} 07^{\prime} 12.9^{\prime \prime}$ & M. micrantha \\
\hline \multirow[t]{6}{*}{ East Jayantia Hills } & Sutnga village (Site A) & $\mathrm{N} 25^{\circ} 22^{\prime} 45.2^{\prime \prime}$ E $092^{\circ} 26^{\prime} 57.8^{\prime \prime}$ & M. micrantha \\
\hline & $\begin{array}{l}\text { Sutnga village } \\
(\text { Site B })\end{array}$ & $\mathrm{N} 25^{\circ} 22^{\prime} 29.9^{\prime \prime}$ E $092^{\circ} 26^{\prime} 24.2^{\prime \prime}$ & $\begin{array}{l}\text { M. micrantha, } A \text {. } \\
\text { conyzoides }\end{array}$ \\
\hline & TongsiangNong-KhltehVillag & $\mathrm{N} 25^{\circ} 19^{\prime} 37.9^{\prime \prime} \mathrm{E} 092^{\circ} 30^{\prime} 08.1^{\prime}$ & M. micrantha \\
\hline & Dkhiah Village & $\mathrm{N} 25^{\circ} 22^{\prime} 01.4^{\prime \prime} \mathrm{E} 092^{\circ} 21^{\prime} 0.13^{\prime \prime}$ & Spilanthes paniculata \\
\hline & Sohshrieh Village & $\mathrm{N} 25^{\circ} 26^{\prime} 6.3^{\prime \prime} \mathrm{E} 092^{\circ} 17^{\prime} 35.4^{\prime \prime}$ & conyzoides \\
\hline & \begin{tabular}{|lll} 
SonapurNarpooh & Reserve & Forest, \\
Jowai
\end{tabular} & $\mathrm{N} 25^{\circ} 05^{\prime} 28.7^{\prime \prime}$ E $092^{\circ} 21^{\prime} 25.0^{\prime \prime}$ & M. micrantha \\
\hline \multirow[t]{8}{*}{ East Khasi Hills } & $3^{\text {rd }}$ Mile & $\mathrm{N} 25^{\circ} 30.359^{\prime} \mathrm{E} 091^{\circ} 40.965^{\prime}$ & $\begin{array}{l}\text { A. conyzoides were noticed; but no } \\
\text { disease was found. }\end{array}$ \\
\hline & Ichamati & $\mathrm{N} 25^{\circ} 10^{\prime} .04 .4^{\prime \prime}$ E $091^{\circ} 41^{\prime} 18.2^{\prime \prime}$ & M. micrantha \\
\hline & Shellapunji & $\mathrm{N} 25^{\circ} 10^{\prime} 86.3^{\prime \prime E} 091^{\circ} 38^{\prime} 026^{\prime \prime}$ & $\begin{array}{l}\text { M. micrantha, C. odorata, and } \\
\text { A. conyzoides }\end{array}$ \\
\hline & Laitkynsew Village & $\mathrm{N} 25^{\circ} 13^{\prime} 11.5^{\prime \prime} \mathrm{E} 091^{\circ} 40.04^{\prime \prime}$ & S. paniculata \\
\hline & $\begin{array}{l}\text { Upper Shillong, Sangmein Terrestrial } \\
\text { Division }\end{array}$ & $\mathrm{N} 25^{\circ} 32^{\prime} 22.4^{\prime \prime}$ E09150'54.3 & M. micrantha \\
\hline & Sohra Forest Range & N 25⒔029'E $091^{\circ} 43.405^{\prime}$ & \multirow[t]{3}{*}{ No weeds found in these places } \\
\hline & Thangkhang Village & $\mathrm{N} 25^{\circ} 12.99 .3^{\prime \prime} \mathrm{E} 91^{\circ} 43^{\prime} 85.4^{\prime \prime}$ & \\
\hline & Mawngap & $\mathrm{N} 25^{\circ} 28.88^{\prime} \mathrm{E} 91^{\circ} 45.407^{\prime \prime}$ & \\
\hline \multirow[t]{4}{*}{ East Garo Hills } & Rongrengre Reserve & $\mathrm{N} 25^{\circ} 32^{\prime} 46.3^{\prime \prime} \mathrm{E} 090^{\circ} 09^{\prime} 04.1^{\prime \prime}$ & C. odorata \\
\hline & Khocshinegsak & $\mathrm{N} 25^{\circ} 30^{\prime} 65.1^{\prime \prime} \mathrm{E} 090^{\circ} 06.9^{\prime \prime}$ & C. odorata \\
\hline & Chisobibra Village & $\mathrm{N} 25^{\circ} 30.655^{\prime} \mathrm{E} 090^{\circ} 08.253^{\prime}$ & C. odorata \\
\hline & Nenkhara Village & $\mathrm{N} 25^{\circ} 30.356^{\prime} \mathrm{E} 090^{\circ} 49.959^{\prime}$ & M.micrantha \\
\hline \multirow[t]{5}{*}{ North Garo Hills } & Wagachi & $\mathrm{N} 25^{\circ} 49^{\prime} 29.3^{\prime \prime}$ E $090^{\circ} 47^{\prime} 10.7^{\prime \prime}$ & M. micrantha \\
\hline & Dangkhong area & $\mathrm{N} 25^{\circ} 51^{\prime} 09.2^{\prime \prime}$ E $090^{\circ} 47^{\prime} 08.8^{\prime \prime}$ & $\begin{array}{l}\text { M. micrantha, C.odorata, and } \\
\text { A. conyzoides. }\end{array}$ \\
\hline & Soinang (Upper) & N2551'51.3" E090³7'025.6” & C. odorata \\
\hline & Thapa Darengri & $\mathrm{N} 25^{\circ} 50^{\prime} 07.0^{\prime \prime} \mathrm{E} 091^{\circ} 35^{\prime} 55.8^{\prime \prime}$ & M. micrantha \\
\hline & \begin{tabular}{|l|} 
Sapicol \\
\end{tabular} & $\mathrm{N} 25^{\circ} 48^{\prime} 21.7^{\prime \prime} \mathrm{E} 090^{\circ} 37^{\prime} 07.1^{\prime \prime}$ & M. micrantha \\
\hline \multirow{3}{*}{$\begin{array}{l}\text { South West Khasi } \\
\text { Hills }\end{array}$} & Mawlyngroh & N25 $14.55 .6^{\prime}$ E $091^{\circ} 24.58 .8^{\prime}$ & M. micrantha \\
\hline & Wahkaji & $\mathrm{N} 25^{\circ} 22.169^{\prime}$ E $091^{\circ} 15.756^{\prime}$, & A. conyzoides \\
\hline & Phottdei Village & N2523.352”E 091²3. 190”, & No species found \\
\hline
\end{tabular}




\begin{tabular}{|c|c|c|c|}
\hline & Sakwang Village & N25 $23.374^{\prime}$ E $091^{\circ} 28.842^{\prime}$, & A. conyzoides \\
\hline & Mawsaw Dom Shrah & $\mathrm{N} 25^{\circ} 25.425^{\prime}$ E $091^{\circ} 22.513^{\prime}$, & No species found \\
\hline & Mawlangbang Village & N2522.964' E 091²3. 830', & A. conyzoides \\
\hline \multirow[t]{5}{*}{ West Khasi Hills } & Nongstein & N2530.610’ E $091^{\circ} 13.705^{\prime}$ & A. conyzoides \\
\hline & Wahlulu & N2532.222' E 09140. 773', & A. conyzoides \\
\hline & Nongtraw Village & N2529.679' E $091^{\circ} 08.558^{\prime}$ & A. conyzoides, $M$. micrantha \\
\hline & Mairang Langstiehrim & N2534.281' E 09138. 121', & No species found \\
\hline & Riangdo & $\mathrm{N} 25^{\circ} 40.111^{\prime}$, E $091^{\circ} 03.940^{\prime}$ & M. micrantha \\
\hline \multirow{2}{*}{$\begin{array}{l}\text { South West Garo } \\
\text { Hills }\end{array}$} & Balnangre & $\mathrm{N} 25^{\circ} 35^{\prime} 11.4^{\prime \prime} \mathrm{E} 90^{\circ} 02^{\prime} \mathrm{F} 35.2^{\prime \prime}$ & C. odorata \\
\hline & Wakka Akonggre & $\mathrm{N} 25^{\circ} 30.055^{\prime} \mathrm{E} 090^{\circ} 08.253^{\prime}$ & C. odorata \\
\hline
\end{tabular}

In vivo evaluation of isolated fungi at Rain Forest Research Institute (RFRI), Jorhat campus

Four different fungi were used for in vivo study at RFRI, Jorhat campus. The fungi were mass cultured in PDB (Potato Dextrose Broth) media. The PDB along with the full grown mycelial mat was then mixed with sterile water to prepare a final concentration of 3 per cent spray solution. Jaggery (a) 10 per cent was also mixed with the spray solution so as to serve as a sticking agent. Spraying of biocontrol agent was done at an interval of 10 days on target weeds, viz., Mikania micrantha, Chromolaena odorata and Spilanthes paniculata. Control plants were maintained by spraying sterile distilled water.

\section{Observations}

Observations on mortality of the target weed species were recorded at an interval of 7 days after each spray and disease incidence was recorded. Mean increase or decrease of the disease development after the treatment was calculated in comparison to control.

\section{RESULTS AND DISCUSSION}

The survey indicated the ubiquitous presence of Mikania micrantha and Chromolaena odorata in the state whereas Ageratum conyzoides and Spilanthes paniculata were present only in a few districts. Spermacoce hispida was found only in Ri-Bhoi district.

A total of six pathogenic fungi were isolated from infected leaves of these target weeds. Of these, two fungi isolated from leaf spot and leaf necrosis disease of $M$. micrantha were identified as Gliocladium roseum and Phomopsis sp. respectively. The fungi isolated from $S$. paniculata, C. odorata, A. conyzoides were identified as Fusarium solani and from S. hispida as F. acuminatum.

\section{Studies on symptomatology \\ Mikania micrantha leaf spot}

The most common disease found on M. micrantha was leaf spot. Initial symptoms appeared as minute pale brown spots which enlarge to form irregular spots with grey centers and dark brown margins. This disease is widespread in Meghalaya.

The fungus isolated from leaf spot of M. micrantha was identified as Gliocladium roseum (ITCC No. 10,720.18). The fungus grows rapidly in culture producing spreading colonies with a cottonlike texture, covering a petri-dish in 1 week. The colonies are white and cream- like. The species produces hyphae, conidiophores and conidia borne from hyaline phialides. The conidiophores are erect, dense and have a brush - like structure which produce tapering, slimy phialides.

\section{Leaf necrosis}

Initial symptoms appeared as pale brown spot on the leaf lamina. Later on, the spots enlarged in size and coalesced to form large necrotic areas.The fungus isolated from leaf necrosis of M. micrantha was identified as Phomopsis sp. (ITCC No. 10.721.18). The colony was initially white in colour, cottony growth with straight mycelium. Later, colony became greyish in colour. Mycelia were septate. Pycnidia were dark, ostiolate, immersed, erumpent, almostglobose. Conidiophores were simple. Conidia hyaline, 1 celled, of two types, ovoid to fusoid conidia and filiform, curved or bent stylospores (beta conidia).

\section{Chromolaena odorata leaf spot}

Symptoms appeared as irregular, brown to dark brown spots of various sizes scattered all over the leaf lamina. Both young and older leaves were found infected. The fungus isolated from C. odorata was identified Fusarium solani (ITCC No. 10,722.18). The colonies are usually fast growing, pale or bright coloured with or without a cottony aerial mycelium. Most of the Fusarium sp. produced both macro and micro conidia from slender and simple phialides. Macro conidia hyaline, two to several cell, fusiform to sickle shaped conidia, mostly with an elongated apical cell and pedicaellate basal cell. Micro conidia one or two celled, hyaline, pyriform-fusiform to ovoid, straight. Chlamydo spore may be present or absent. 


\section{Spilanthes paniculata and Ageratum conyzoides}

On Spilanthes paniculata symptoms appeared as brown necrotic lesion starting from the tip and spreading downward through the leaf margin. Distribution of the disease is very restricted and collected only from $S$. paniculata grown in swampy areas. On Ageratum conyzoides initial symptoms appeared as irregular brown necrotic lesion on the leaf margin. Later on, enlarged in size and covered the entire leaf surface.

The fungus isolated from S. paniculata, A. conyzoides (ITCC No. 10,723.18, 10,724.18) was identified as Fusarium solani. So, the characteristics are same as the above.

\section{Spermacoce hispida}

The fungus isolated from Spermacoce hispida was identified as Fusarium acuminatum (ITCC No. 10,725.18). The colonies are usually fast growing, bright coloured with or without a cottony aerial mycelium. Most of the Fusarium $s p$. produced both macro and micro conidia. Oval to kidney shaped micro conidia and sickle- shaped, thin walled and delicate macroconidia. Micro conidia produced in false heads on short monophialides. Chlamydospore may be present or absent.

Results of pathogenicity test revealed that all the isolated fungi were found infecting the weeds from which they were isolated, whereas only maize and tomato were found infected.

Pathogenicity test carried out on seedlings of some economically important tree species of Meghalaya, viz., Pinus kesiya, Magnolia champaca, Alnus nepalensis, Chukrasia tabularis, Exbucklandia populnea and Castanopsis indica revealed that the isolated fungi were not infecting the seedlings.

In vivo application of isolated fungus on Mikania micrantha (leaf necrosis and leaf spot), Chromolaena odorata and Spilanthes paniculata was carried out in RFRI campus.

In the present investigation, the two fungal pathogens, viz., Gliocladium roseum and Phomopsis sp. isolated from M. micrantha were different from those fungal pathogens reported from Kerala (Sreenivasan and Sankaran, 2001) and from North East India (Gogoi, 2001). Hence, these two fungal pathogens can be considered as new records on $M$. micrantha from India. Further, the fungus Fusarium solani is also reported to be isolated for the first time from the C. odorata, S. paniculata and A. conyzoides. Chetti et al., (2001) reported three different fungi, viz., Colletotrichum gloeosporiodes, Alternaria alternata and Aureobasidium pullulans to cause diseases on chromolaena. The fungal pathogen $F$. acuminatum isolated from Spermacoce hispida might be considered as an opportunistic fungus as it did not cause any serious damage to the host.

Kaur et al., (2014) also reported the phytotoxicity of Fusarium solani on Parthenium spp. which caused severe chlorosis, necrosis and complete death of the leaves and is similar to our findings.

Phomopsis spp. was also found to be effective in killing the target weeds. Plant mortality occurs more quickly in fungus treated plot as compared to the control which is similar with the findings of Roskopff et al. (2000) where they found $73 \%$ mortality of Amaranthus lividus with a single application of Phomopsis amaranthicola, while within four weeks the mortality rate increased to $95 \%$ after the second spray. In the present investigation, spraying of fungal spore suspension of Fusarium solani on chromolaena infected only the leaves and this finding is similar to that of (Chetti et al., 2001), who also reported that $C$. gloeosporides and $A$. alternate could only infect the leaves.

The present study indicates that the different isolated fungus seems to offer great potential for development and exploitation as effective biocontrol agents against the target weed species in large scale under field condition. Field evaluation of biological effectiveness is one of the most important components of a complete evaluation of a pathogen's weed-control potential. Although a pathogen may perform effectively in greenhouse or growth-chamber experiments, its use in the field is often characterized by variable levels of effectiveness against the target weed. In addition, most synthetic and natural pesticides are susceptible to ineffectiveness due to resistance buildup in different weed species. Thus, the only viable solution for the future is integrated management of weed. The economic benefits and reduced social costs of these systems present a logical answer to the weed control problem.

\section{REFERENCES}

Chetti MB, Hiremath SM, Prashanti SK, Mummigatti UV, Kulkarni. 2001. Survey and Screening of various Pathogens for Biological Control of Chromolaena odorata. Status of Mikania infestation in Northeastern India: Management options and Future Research Thrust, pp. 146-149. In: Sankaran KV, Murphy ST, Evans, HC (Eds.), Alien Weeds in Moist Tropical Zones: Benes and Benefits. Kerela Forest Research Institute, Peechi, Kerala, India.

GogoiAK. 2001. Status of Mikania infestation in Northeastern India: Management options and Future Research Thrust, 
pp. 77-79. In: Sankaran KV, Murphy ST, Evans HC (eds.), Alien Weeds in Moist Tropical Zones: Benes and Benefits. Kerela Forest Research Institute, Peechi, Kerala, India.

Haridasan K, Rao RR. 1985. Forest Flora of Meghalaya. Bishen Singh and Mahendra Pal Singh, Dehradun, Vol. 1.

Kaur M, Aggarwal NK, Kumar V, Dhiman R. 2014. Fusarium solani as biocontrol agent against parthenium weed. Mycopathology 12: 83-86.

Pimentel D, Zuniga R and Morrison D, 2005. Update on the environmental and economic costs associated with alien-invasive species in the United States. Ecol Econom. 52(3): 273-288.

Rao RR, Sagar K. 2012. Invasive alien weeds in the tropics: the changing pattern in the herbaceous flora of Meghalaya in North East India, pp. 189-198. In: Bhatt JR, Singh JS, Singh SP, Tripathi RS, Kohli RK (Eds.). Invasive Alien Plants: An Ecological Appraisal for the
Indian Subcontinent. CABI International, CPI Group (UK) Ltd., Croydon, UK.

Richardson DM, Pysek P, Rejmanek M, Brbour MG, Panetta FD, West CJ. 2000. Naturalization and invasion of alien plants: Concepts and definitions. Divers Distrib. 6, 93-107. https://doi.org/10.1046/j.14724642.2000.00083.x

Rosskopf EN, Charudattan R, DeValerio JT, Stall WM. 2000. Field evaluation of Phomopsis amaranthicola, a biological control agent of Amaranthus spp. Plant Dis. 84: $1225-1230$.

Vitousek PM, D’Antonio C, Loope LL, Rejmanek M, Westbrooks R. 1997. Introduced species: a significant component of human-caused global change. New Zealand J Ecol. 21: 1-16

Waghmare MB, Waghmare RM, Kamble SS. 2011.Bioefficacy of plant extracts on growth of Botrytis cinerea causing leaf blight of rose. Bioscan 6: 643. 